\section{from EDITORS}

『忙しくて〈B-plus〉を読む時間がないという方も，仕事 の合間にパラパラと目を通して頂ければ，きっと一服の 精力剂のように元気がもらえる記事に出会えるのではな いかと思っています．記事を書くのも人，記事を編集す るのも人，そして記事を読むのも人で，人と人との出会 いの場を提供する，そんな人間くさい，わくわくするよう な楽しいマガジンになればと願っています。

(N.K.)

マ人は昔から新しい材料を求めていた。 それは錬金術. メタマテリアルは，構造を工夫することにより新しい特 性を求めたもの. グラフェンはノーベル物理学賞をもた らす.レアメタルを使わないモー夕など, 科学技術の進 歩には, 夢の材料が欠かせない. 出でよ, 新元素, 新 材料.

(M.T.)

本年より，大学という新たな職場で教育・研究職に 従事するようになり, 学生の学習意欲の低下問題, 学 力格差への対処問題, 等々があることを改めて実感し ています．課題は山積していますが，将来の日本のた めにも, 次世代を担う学生の意欲を少しでも引き出して いけるように工夫していく必要があると感じています。

(M.M.)

「技術と制度のおはなし」という連載が始まりました。 研究の成果である「技術」が実際に通信や放送に使わ れるためには, 標準化, 制度化というプロセスが欠かせ ません。研究を進める際にはこれらを意識しておくことも 必要だと思います。この連載が標準, 制度を考えるきっ かけの一つになればと期待しています。

(H.O.)

『歳をとるたびに1年が短くなっていきます．師走になる と忘年会でお酒に吞まれながら「この1年何ができたの かな?」と自問自答するのが恒例になってきました，その 歩みは遅くとも，科学技術同様年々進歩しなければい けないな, と反省する季節です。

(H.S.)

『今年度から編集委員を仰せつかり, 初仕事として「開 発物語」を担当致しました. 学生時代にPC-8001を 10 回ローンで購入し, BASIC と Z-80 マシン語で深夜 までプログラミングしていたことを懐かしく思い出しまし た。その PC-8001を開発された方々の御苦労（特に, 米国 Microsoft との BASIC 開発で苦労されたお話な ど)を，感慨深く知ることができました。

(J.A.)

マブラジルで開催された国際会議に参加しました，南米 といえば, 日本の方式の地上デジタルテレビ放送が話 題になっています. そこで, 日本のケータイでワンセグが 見られるかという期待を持ちましたが，やはりだめでし た.チャネルの違いだけではなく, 映像や音声の符号 化方式も異なっているようです.

(H.T.)

V2010 年ももう終わりです. 日々の仕事に追われてい ると, 1 年はあっという間で, 自分自身を振り返る余裕も ないかもしれません。でも, 学会の中では, 50 年先くら いの未来技術を語り，子供たちなど将来を支える世代 に夢を見せてあげたいです。

(H.S.)

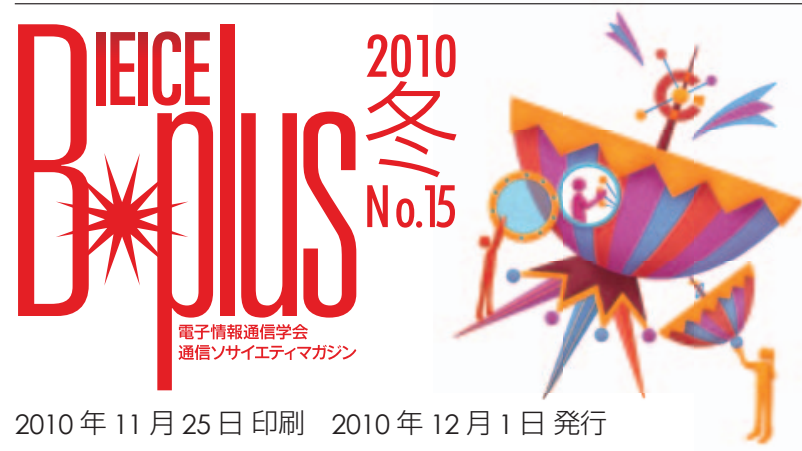

Editorial Board

\begin{tabular}{|c|c|c|c|c|}
\hline $\begin{array}{l}\text { 編 集 委員長 } \\
\text { 編集副委員長 }\end{array}$ & $\begin{array}{l}\text { 山崎克之 } \\
\text { 菊間信良 }\end{array}$ & 山岡克式 & & \\
\hline 編 集委員 & $\begin{array}{l}\text { 赤埴淳一 } \\
\text { 小瀬木滋 } \\
\text { 河東晴子 } \\
\text { 関屋大雄 } \\
\text { 戸出英樹 } \\
\text { ベンジャブー } \\
\text { 南 憲一 }\end{array}$ & $\begin{array}{l}\text { 朝香卓也 } \\
\text { 小野文枝 } \\
\text { 佐波孝彦 } \\
\text { 高橋応明 } \\
\text { 西本 浩 } \\
\text { ル・アナス } \\
\text { 三宅 滋 }\end{array}$ & $\begin{array}{l}\text { 岩井誠人 } \\
\text { 翁長 久 } \\
\text { 清水 聡 } \\
\text { 橘 拓至 } \\
\text { 長谷川輝之 } \\
\text { 馬杉正男 }\end{array}$ & $\begin{array}{l}\text { 大槻知明 } \\
\text { 神尾享秀 } \\
\text { 庄木裕樹 } \\
\text { 辻 宏之 } \\
\text { 濱辺孝二郎 } \\
\text { 松田崇弘 }\end{array}$ \\
\hline
\end{tabular}

2011 年春号（第 16 号） 2011 年 3 月 1 日発行

小特集電気電子情報通信分野での

小特集 ワーク・ライフ・バランス実現に向けて

私の技術者歴石川宏

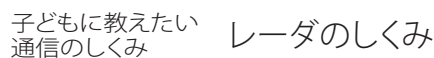

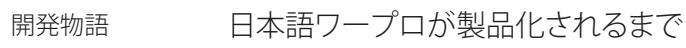

本誌の愛称は「B-plus」, 正式名称は「通信ソサイエティマガジン」, 「IEICE Communications Society Magazine」です.

本誌掲載論文を文献引用する際は，邦文略称「信学通誌」，英文略称 「IEICE Commun. Mag.」を用いて下さい.

\section{【通信ソサイエティマガジン B-plus へのお問い合わせ】}

口御意見，御要望，入手など : b-plus@ieice.org $\square$ ロームページ：

http://www.ieice.org/cs/jpn/pub/magazine/

口複写される方へ: 本会は下記協会に複写に関する権利委 託をしていますので，本誌に掲載された著作物を複写し たい方は，同協会より許諾を受けて複写して下さい.た だし，（社）日本複写権センター（同協会より権利を再委 託）と包括複写許諾契約を締結されている企業の社員に よる社内利用目的の複写はその必要はありません（社外 頒布用の複写は許諾が必要です)

権利委託先：(社) 学術著作権協会

170-0052 東京都港区赤坂 9-6-41 乃木坂ビル Tel : 03-3475-5618 Fax : 03-3475-5619 E-mail : info@jaacc.jp

なお，著作物の転載・翻訳のような複写以外の許諾は，直 接本会へ御連絡下さい.

著作権利用許諾については

http://www.ieice.org/jpn/service/tensaitokkyo/

発行者 / 木暮賢司

発行所 / (社) 電子情報通信学会 通信ソサイエティ

105-0011 東京都港区芝公園 3-5-8 機械振興会館

TEL : 03-3433-6691 (代表) 振替：00120-0-35300

制 作/ (株) エヌ・ピー・エス

111-0051 東京都台東区蔵前 2-5-4 北條ビル

(C) Copyright 2010 IEICE. All rights reserved. 